\title{
Traditional use of Gymnopus nubicola as food resource in a Kichwa community, Pichincha, Ecuador
}

\section{Gamboa-Trujillo $\mathrm{JP}^{1,5 *}$, Wartchow $\mathbf{F}^{2}$, Cerón $\mathbf{C}^{1}$, Aules $\mathbf{E}^{3}$, Aigaje $\mathbf{C}^{3}$, Calvalcanti $\mathrm{LH}^{4}$ and Gibertoni $\mathrm{TB}^{5}$}

\footnotetext{
${ }^{1}$ Universidad Central del Ecuador, Facultad de Ciencias Médicas-Carrera de Ciencias Biológicas y Ambientales, Laboratorio de Biotecnología Industrial - Facultad de Ingeniería Química, Centro de Transferencias y Desarrollo de Tecnologías CTT-UCE, Sección Micológica del Herbario Alfredo Paredes - Sección Micológica del Herbario Nacional QCNE, Sección Micológica del Jardín Micológico Herbario QAP, Ciudadela Universitaria, Quito, Pichincha, Ecuador. 05933216344 ext.20

${ }^{2}$ Universidade Federal da Paraíba, Departamento de Sistemática e Ecologia/CCEN, CEP: 58051-970, João Pessoa, $P B, B R A Z I L$

${ }^{3}$ Members of the community of Cangahua, Cayambe, Ecuador

${ }^{4}$ Universidade Federal de Pernambuco, Departamento de Botânica/CCB, Av. Prof. Nelson Chaves, $s / n^{o}$, CEP: 50670901, Recife, PE, Brazil

${ }^{5}$ Universidade Federal de Pernambuco, Departamento de Micologia/CCB, Av. Prof. Nelson Chaves, $s / n^{\circ}$, CEP: 50670-901, Recife, PE, Brazil
}

Gamboa-Trujillo JP, Wartchow F, Cerón C, Aules E, Aigaje C, Calvalcanti LH, Gibertoni TB 2014 - Traditional use of Gymnopus nubicola as food resource in a Kichwa community, Pichincha, Ecuador. Mycosphere 5(1), 180-186, Doi 10.5943/mycosphere/5/1/9

\begin{abstract}
Gymnopus nubicola is characterized by a strong smell and pleasant flavour, by a dark reddish brown to brick red pileus, adnexed, whitish to cream lamellae, inamyloid, hyaline, ellipsoid to lacrimoid basidiospores. Indigenous communities of Kichwa nationality, that inhabit vegetal formations called "páramos" of the Ecuadorian Andes, call it kallambas or kallambitas and use the mushrooms for direct alimentation. Sporadically it is sold in popular markets close to the communities. Gymnopus nubicola is hereby reported for the first time as an edible mushroom in the world.
\end{abstract}

Keywords - Andean 'kichwa' communities - mushrooms - edible - 'kallambas'- Ecuador

\section{Introduction}

Recent researches reported the edibility of several species of mushrooms in South America. Henkel et al. (2004) reported 17 taxa as the highest appreciated food of the Patamona in French Guyana, including Amanita perpheae Simmons, T.W. Henkel \& Bas, Lentinula cf. boriana (Mont.) Pegler and unidentified taxa of Clavulina and Pleurotus. In the Venezuelan Amazon, Zent et al. (2004) described the mycophagous behavior of the Hotï community, reporting 11 taxa of macrofungi. Among them, Auricularia spp., Lenzites spp., Polyporus spp., and Macrocybe titans (H.E. Bigelow \& Kimbr.) Pegler, Lodge \& Nakasone were identified.

Gamboa-Trujillo (2005) already reported that mushrooms are consumed by several ethnicities in Ecuador. In the Andean highlands ('páramos'), the Kichwa communities are established in forests of the "Sierra" region. This isolated location allowed the preservation of their 
behavior, language, commerce and cultural contact among communities regardless of the influence of Spanish colonization. However, subsistence activities such as hunting, fishing, seed gathering and cultivation (Proel 2007) and mushroom collecting, consuming and selling in popular markets are disappearing (Gamboa-Trujillo 2005).

The aim of this work is therefore to improve the knowledge about ethnomycology in Ecuador, with the discussion of the traditional use as food resource of an edible species used by the Kichwa communities in the Andes.

\section{Materials \& Methods}

Popular markets in the cities of Cayambe (Pichincha province) and Otavalo (Imbabura province) and communities in the locality of Cangahua (canton Pedro Moncayo, Cayambe) were visited, mostly during the rainy season (September to December 2010 and 2011, and January 2011 and 2012), corresponding to the fructification period of edible mushrooms in the Ecuadorian highlands. Informal interviews were performed with sellers of the Kichwa community, for the purpose of obtaining data about fresh weight of the basidiomas, prices in the market, forms of consumption and days in which the mushrooms are harvested and brought to popular markets for selling, according to Chang and Lee (2004).

The macroscopic characteristics of the species, such as size, color, substrate and habitats, were taken during collection in the 'páramo'. Microscopic analyzes were performed at the Herbário Alfredo Paredes (QAP), Universidad Central del Ecuador, and at the Departamento de Micologia, Universidade Federal de Pernambuco. Basidiospores data follows the methodology proposed by Tulloss et al. (1992), slightly modified by Wartchow (2012) and Wartchow et al. (2012). Measurements and statistics are based on 20 basidiospores. The specimens were identified according to Halling (1996) and the fungal specimens were deposited at the herbaria QAP, URM and JPB (Thiers 2013).

\section{Results}

Among the collected species, Gymnopus nubicola Halling (Marasmiaceae) (Fig. 1A, B) was identified. It is morphologically characterized by the brick red, 20-30 (-48) mm, convex pileus; whitish to cream lamellae; inamyloid, hyaline, ellipsoid to lacrimoid, thin-walled basidiospores 5$6.8(-7) \times(2.5-) 3-3.5(-4) \mu \mathrm{m}, \mathrm{L}=5.4 \mu \mathrm{m} ; \mathrm{W}=3.1 \mu \mathrm{m}, \mathrm{Q}=(1.68-) 1.72-2.34, \mathrm{Qm}=1.89$; very inconspicuous cheilocystidia; pileipellis made of repent to most frequently interwoven branched hyphae, not coralloid nor diverticulate (a 'dryophila-type'); and clamps connections abundant in all tissue (Halling 1996). The basidiomata have a strong and pleasant odour, similar to Lentinula edodes (Berk.) Pegler ('shiitake').

Gymnopus nubicola was described from Ecuador (Halling 1996) and now is for the first time reported as an edible species in the world. In Ecuador, it is distributed in the vegetal formation called 'páramos', on soil, at an altitude of $2555 \mathrm{~m}$ a.s.l., together with Lachemilla orbiculata (Ruiz \& Pav.) Rydb. (Rosaceae) and Azorella pedunculata (Spreng.) Mathias \& Constance (Apiaceae). These plant species are very abundant in this ecosystem and are locally denominated as "almohadillas".

The harvest of this species is generally performed during the rainy season (winter) (September to December) and, according to folk's information, its occurrence is associated with major incidence of lightning and thunder (Gamboa-Trujillo 2005). This belief is also observed for other mushrooms, such as Agaricus pampeanus Speg. (Gamboa-Trujillo 2005).

In the region where $G$. nubicola is harvested, women, men and even children have great experience in searching edible mushrooms, distinguishing them from the non-edible species by colour, odour and stage of growth. Younger basidiomata are the preferable ones, because they are usually not rotten and have more pleasant texture. This information is transmitted to their children, which acquire experience in recognizing, in the field, mushrooms in good condition to eat (Fig. 2A, $\mathrm{B})$, and are taught that it is important to wash and cook the mushrooms before eating. According to 

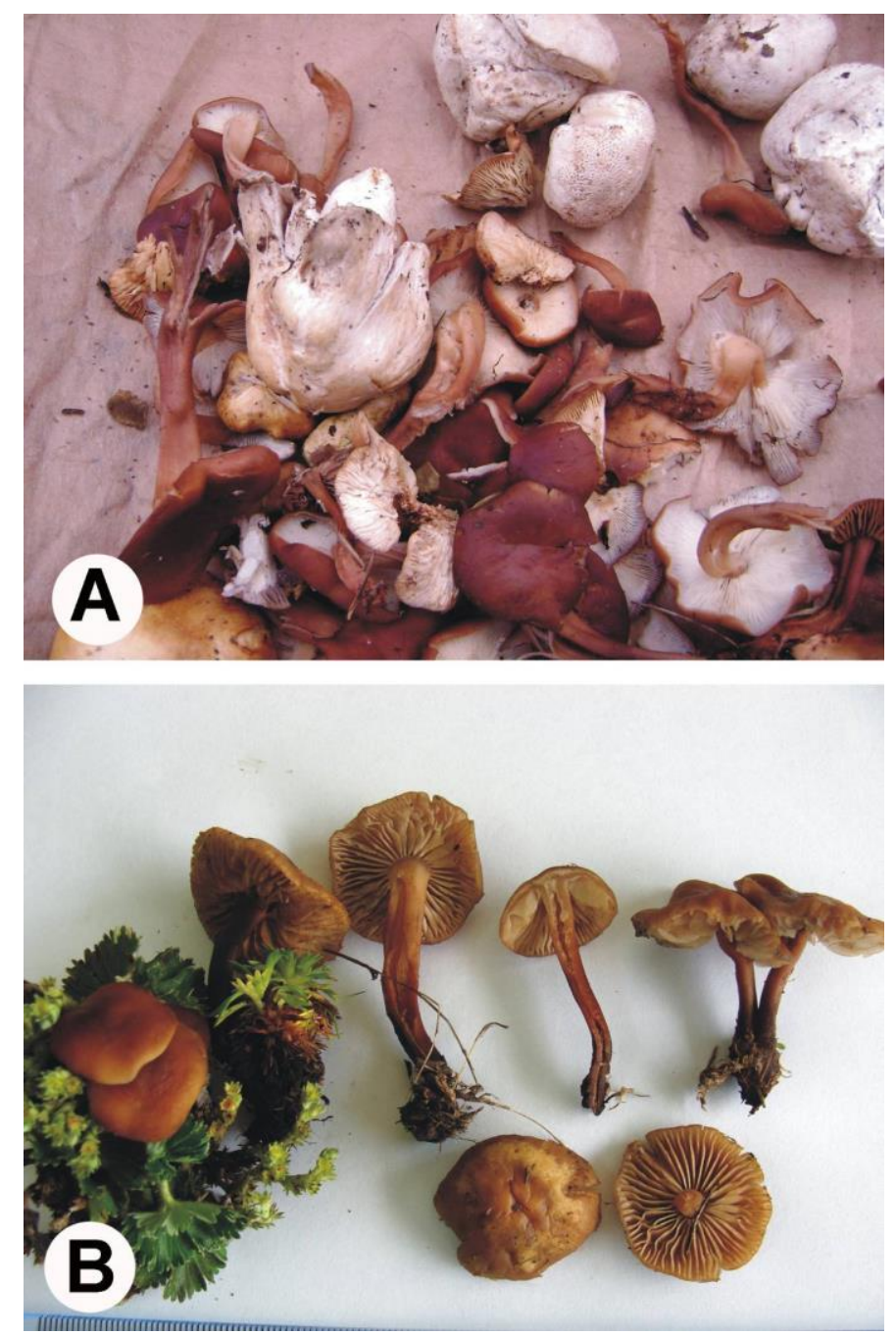

Fig. 1 - A, Sale of Gymnopus nubicola with Calvatia sp. ('supe'). B, Details of basidiomata of Gymnopus nubicola at laboratory. This picture is copyright of Paúl Gamboa-Trujillo.

the police department and the staff of the Raúl Maldonado Hospital in the city of Cayambe, no record of poisoning after eating wild mushrooms was reported until 2012. This shows the importance of these folks acquiring experience in occasional harvest of wild mushrooms since childhood.

This mushroom is known as 'kallamba' by the the Kichwas in the Ecuadorian Andes. 'Kallamba' is a vernacular name in Kichwa language that corresponds to the general term 'hongo' in Spanish and "mushroom" in English. Gymnopus nubicola does not have a traditional epithet, differently from Agaricus pampeanus and A. argyropotamicus Speg., which are also sold in popular markets and are known by the binomial traditional name 'kallamba de finados' (Day of the Dead's mushrooms), because basidiomata production is in November, when the Day of the Dead is celebrated (Gamboa-Trujillo 2005, Fig. 3A).

The fourth author (Aules E.) reports the harvesting and preparation of the basidiomata in the following way:

"Las kallambitas son cojidas en el páramo, allá lejos en el cerro por eso cuando vamos a tolar o a cosechar las papas y las cebollas y nos encontramos con las kallambitas les cogemos en un balde o el costa, después les llevamos a la casa y les lavamos bien con agua de la asequía sacando los animalitos que saben estar dentro del sombrerito, de ahí les ponemos en agua hervida con sal y les mezclamos con papas y también nos comemos con huevos duros.... esto nos han enseñado nuestros papás y abuelos y nunca nos hizo daño ...." 

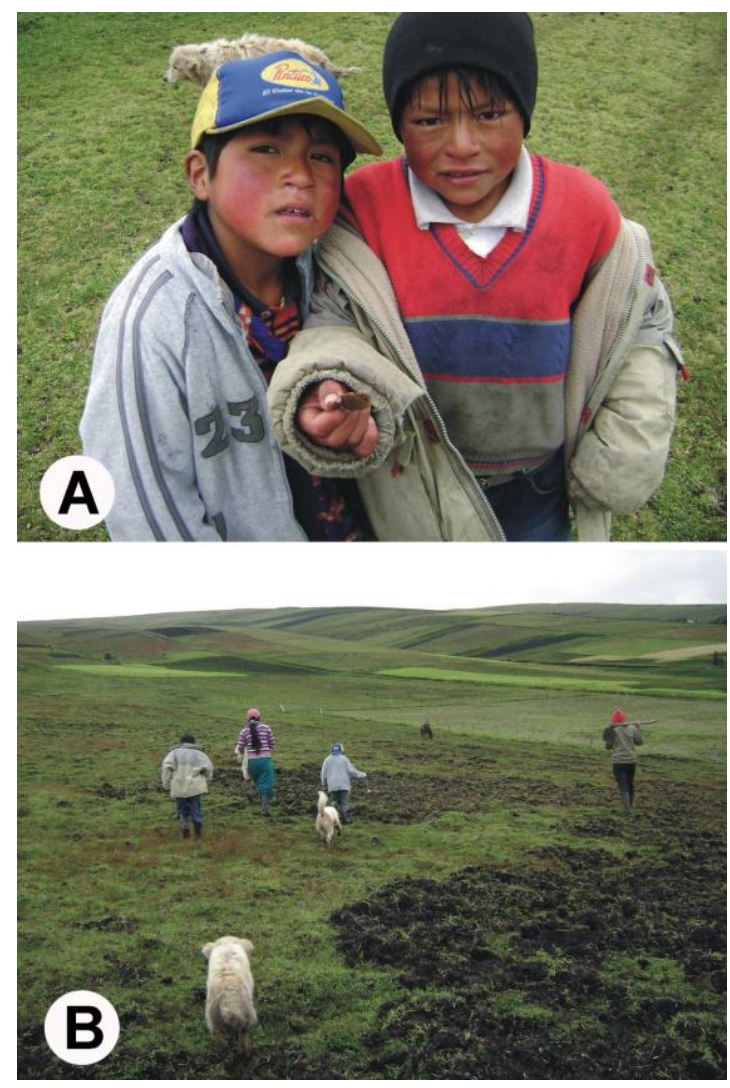

Fig. 2 - A, Children playing with Gymnopus nubicola. B, Children accompanying their parents during mushrooms harvesting in the "páramos". This picture is copyright of Paúl Gamboa-Trujillo.

"The mushrooms (kallambitas) are collected in the highlands (páramos), far away on the hills. For this reason, when we go to harvest the potatoes and onions, we find the mushrooms (kallambitas), collect them in a basket or a bag, then we carry them home and wash them with river water. After that, small animals that are inside the hat are taken out, and then we put the mushrooms in boiled water with salt and mix them with potatoes or boiled eggs... it was taught to us by our parents and grandparents, and never caused us any harm ...".

In general, the community harvests $G$. nubicola in plastic or aluminum containers, but this edible species used to be collected in baskets of natural fibre of Arundo donax L. (Poaceae), known as 'carrizo'. According to the interviewed people, the current use of plastics bags or metal pots accelerates the process of decomposition of the mushrooms, but the replacement of the baskets by metal or plastic containers is due to the fact that the baskets are not frequently made anymore and, thus, are highly priced.

Gymnopus nubicola is offered for sale on Fridays on the market of Juan Montalvo in Cayambe and Saturdays on the popular market in Otavalo. The basidiomata are frequently commercialized in plastic bags with other species of edible mushrooms, such as A. pampeanus and A. argyropotamicus (Fig. 3A), rarely with an edible unidentified Calvatia sp. which carries the vernacular name 'supe' (Fig. 1A). Each portion of G. nubicola is sold in a quantity of approximately $150 \mathrm{~g}$ and costs USD 1 (1 kg approximately USD 6,6). The collection and commercialization of $G$. nubicola constitute an additional economic resource for several families in that region, because the main products sold are portions ('guangos', aprox. $500 \mathrm{~g}$ ) of onions (at USD 0.75) (Fig. 3B) and $14 \mathrm{~kg}$ of potatoes (USD 3) during the higher production season. Mushroom selling is important for several families, because there is no cost in collecting them in the wilderness, differently of onions and potatoes that must be planted, requiring time and money. The sellers also report that the sale of the mushrooms helps them to pay for the bus ticket (USD 0.25 ) or to have lunch (USD 1.50). In case of the absence of people interested in buying mushrooms, the mushrooms are taken back home to be consumed. 


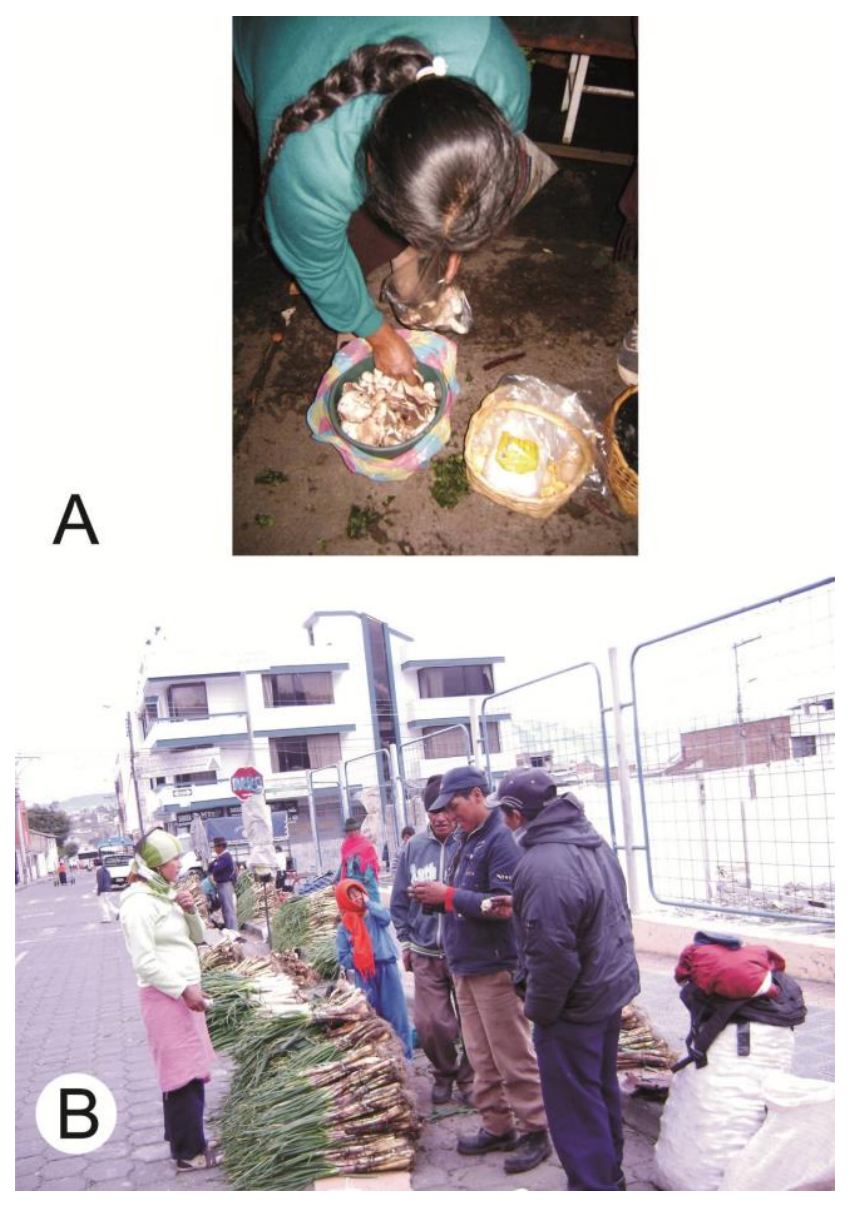

Fig. 3 - A, Agaricus pampeanus and Agaricus argyropotamicus sold in plastic containers in the same as Gymnopus nubicola. B, Selling of onion and Gymnopus nubicola in Otavalo, Imbabura province. This picture is copyright of Paúl Gamboa-Trujillo.

Few people remain selling natural products. According to interviewed people, the sale of wild mushrooms, as well as other natural products rich in proteins, fibres and minerals, decrease each year due to the preferable consumption of industrialized food, of easier access.

\section{Discussion}

Usually, species of Marasmiaceae are infrequently reported as edible. In Africa, Antonín (1998) described Marasmius heinemannianus Antonín from the Atacora province, Benin, and it is also consumed and sold in markets. The species is well known by the local people by the name 'bawafobi' (Antonín 1998). More recently, two species of Gymnopus were referred as edible in Africa. Van Dijk et al. (2003) reported Gymnopus cf. allegretti (De Seynes) A.W. Wilson, Desjardin \& E. Horak (as Collybia cf. allegretii) to be edible by the Bantu and Bagyeli people in Cameroon, where it is known by the name 'mbomini'. Later, Antonín et al. (2005) described a collection of $G$. tamatavae (Bouriquet) Antonín, Buyck \& Randrianjohan that is reported as frequently offered for sale in Madagascar, but no vernacular name was informed by these authors.

In Latin America, the only species reported so far was G. dryophilus (Bull.) Murrill. It is offered for sale in popular markets in Mexico, in the states of Tlaxcala, Puebla and Morelos, where is sold with basidiomata of Lactarius spp., Russula spp., Laccaria spp., Helvella spp. and Clitocybe spp. (Montoya et al. 2001, Pérez-Moreno et al. 2008). Gymnopus dryophilus is known by the vernacular name 'paraguitas' (small umbrellas) and 'popotitos' (skinny people) (Montoya et al. 2001) and also 'orejitas' (small ears) due to the cartilaginous consistency of the basidiomata (PérezMoreno et al. 2008). On the other hand, the Ecuadorian Kichwa's vernacular name for G. nubicola ('kallamba') is not related to any object or part of human body, but means only mushroom. 
Similar to Ecuador, in Mexico, the mushrooms are collected mostly by women, but occasionally by their husbands and children during the rainy season (July) (Montoya et al. 2001, Pérez-Moreno et al. 2008). However, in Mexico the mushrooms are harvested in Pinus and Quercus forests, while in Ecuador it is collected in 'páramo', herbaceous vegetation in the Andes.

Regarding to price for sale, Montoya et al. (2001) reported macrofungi prices as varying from USD 0.40 to 8 per kilo (G. dryophilus not included), similar to the observed for G. nubicola in our study. Currently, there is no information about preparation and price of these edible species of Marasmiaceae, being this the first record of a traditional recipe and value for a species of the family.

Apparently, baskets made of natural fibres are still widely used for harvest and selling by local people in Madagascar and Mexico (Montoya et al. 2001, Antonín et al. 2005, Pérez-Moreno et al. 2008), contrary to the observed in our study.

In our study, it was observed that the local people who sell mushrooms acquire experience through knowledge flow from generation to generation and that this knowledge was has not been deeply investigated for many years possibly because selling these organisms is not frequent. Besides that, the trade of wild mushrooms is decreasing due the replacement for industrialized food as alimentation resource. This kind of food is considered to be one of the most important factors causing most common diseases like cancer and diabetes in urban areas (Horrigan et al. 2002). Those diseases are still less frequent (J.P. Gamboa-Trujillo, pers. observ.) in Kichwa populations probably due to the use of natural food, such as vegetables, fruits, mushrooms and wild animals, free of chemical preservatives and artificial compounds.

The preservation of the 'páramos' in Ecuador is important to the protection of fungal resources mainly the edible wild macrofungi, which constitute an important part of mycophagous and mycophylous customs of indigenous communities. Hence, it is suggested that local government stimulates projects using edible macrofungi for sustainable development of local economy and as a way to contribute to the conservation of the native mycobiota and of the traditional knowledge.

\section{Acknowledgments}

The authors thank the Herbário Alfredo Paredes and Centro de Transferencias y Desarrollo de Tecnologías (Universidad Central del Ecuador) for providing their infrastructure; Dr. Plutarco Naranjo (in memoriam), Dr. Maria Auxiliadora de Q. Cavalcanti, Dr. Leonor C. Maia and Dr. Fátima de Andrade for suggestions and improvements of the manuscript; Stefan Brück for English improvements. The authors thank SENESCYT (Ecuador) and CAPES (Brazil) for providing master and doctorate scholarship to JPGT, and CNPq (Brazil) and Programa de Pós-Graduação em Biologia de Fungos (Universidade Federal de Pernambuco, Brazil) for partially financing this research. This work is dedicated to Dr. Plutarco Naranjo (in memoriam), for great contribution to the research of ethnomedicine in Ecuador.

\section{References}

Antonín V, 1998 - Marasmius heinemannianus, a new edible species from Benin, West Africa. Belgian Journal of Botany 131, 127-132.

Antonín V, Buyck B, Randrianjohan E, Duhem B, 2005 - Edible mushrooms from Madagascar (1), notes on Collybia tamatavae. Cryptogamie, Mycologie 26, 105-111.

Chang YS, Lee SS, 2004 - Utilization of macrofungi species in Malaysia. Fungal Diversity 15, 1522.

Gamboa-Trujillo JP, 2005 - Diversidad y etnomicología de macromycetos, Cuenca Alta del Río Oglán, Pastaza, Ecuador. Cinchona 6, 95-110.

Halling RE. 1996 - Notes on Collybia V. Gymnopus section Levipedes in tropical South America, with comments on Collybia. Brittonia 48, 487-494.

Henkel TW, Aime MC, Chin M, Andrew C, 2004 - Edible mushrooms from Guyana. Mycologist 18, 104-111. 
Horrigan L, Lawrence RS, Walker P, 2002 - How sustainable agriculture can address the environmental and human health harms of industrial agriculture. Environmental Health Perspectives 110, 445-456.

Montoya A, Estrada-Torres A, Kong A, Juárez-Sánchez L, 2001 - Commercialization of wild mushrooms during market days of Tlaxcala, Mexico Micología Aplicada Internacional 13, $31-40$.

Pérez-Moreno J, Martinez-Reyes M, Yescas-Pérez A, Delgado-Alvarado A, Xoconostle-Cázares B, 2008 - Wild mushrooms markets in Central Mexico and a Case study at Ozumba. Economic Botany 62, 425-436.

PROEL - Promotora Española de Lingüística, 2007 - Lenguas Amerindias. http://www.proel.org/index.php?pagina=mundo/amerindia/andinoec/quechuama, accessed in 07 August 2012.

Thiers B, 2013 - [continuously updated]. Index Herbariorum: A global directory of public herbaria and associated staff. New York Botanical Garden's Virtual Herbarium. Avaliable<http://sweetgum.nybg.org/ih/> accessed 13 February 2013.

Tulloss RE, Ovrebo CL, Halling RE, 1992 - Studies on Amanita (Amanitaceae) from Andean Colombia. Memoirs of the New York Botanical Garden 66, 1-46.

Van Dijk H, Onguene NA, Kuyper TW, 2003 - Knowledge and utilization of edible mushrooms by local populations of the rain forest of South Cameroon. AMBIO: A Journal of the Human Environment 32, 19-23.

Wartchow F, 2012 - Clavulina incrustata, a new species from Pernambuco, Brazil. Cryptogamie, Mycologie 33, 105-113.

Wartchow F, Buyck B, Maia LC, 2012 - Cantharellus aurantioconspicuus (Cantharellales), a new species from Pernambuco, Brazil. Nova Hedwigia 94, 129-137.

Zent EL, Zent S, Iturriaga T, 2004 - Knowledge and use of fungi by a mycophilic society of the Venezuelan Amazon. Economic Botany 58, 214-226. 